\title{
HUBUNGAN KEADAAN SOSIAL EKONOMI DAN TINGKAT STRES DENGAN KEJADIAN HIPERTENSI \\ Made Mahaguan Putra ${ }^{12}$, I Kadek Nova Darmayasa', Putu Agus Winduyasa \\ Bukian $^{1}$, Aris Widiyanto ${ }^{3}$, Joko Tri Atmojo ${ }^{3}$ \\ ${ }^{1}$ Prodi S1 Keperawatan, Sekolah Tinggi Ilmu Kesehatan Buleleng \\ ${ }^{2}$ International Nurse Training Center Bali \\ ${ }^{3}$ Prodi D3 Keperawatan, Sekolah Tinggi Ilmu Kesehatan Mamba'ul 'Ulum Surakarta \\ Email:md.mahagunaputra@gmail.com
}

\begin{abstract}
Abstrak
Pendahuluan. Salah satu faktor yang mempengaruhi tekanan darah adalah stres. Tingginya tingkat stres umumnya disebabkan karena faktor sosial ekonomi keluarga yang memiliki tekanan tersendiri, sehingga secara tidak langsung faktor sosial ekonomi juga dapat mempengaruhi kejadian hipertensi seseorang. Tujuan. menganalisis hubungan antara keadaan sosial ekonomi dan tingkat stres dengan kejadian hipertensi. Metode. Jenis penelitian ini deskriptif korelasional dengan rancangan cross sectional yang bertujuan untuk mengkaji hubungan antara keadaan sosial ekonomi dan tingkat stres dengan kejadian hipertensi. Penelitian ini menggunakan sampel sebanyak 93 responden dengan tehnik simple random sampling. Result. Hasil analisis data dengan uji korelasi rank spearman di dapatkan nilai $(\alpha: 0,000)$. Kesimpulan. Ada hubungan yang signifikan yang artinya ada hubungan antara sosial ekonomi dan stres dengan kejadian hipertensi di Wilayah Kerja Puskesmas Sawan II.
\end{abstract}

Kata kunci : Sosial Ekonomi, Stres, Hipertensi

\begin{abstract}
Introduction. One of the factors that affect blood pressure is stress. The high level of stress is generally caused by family socio-economic factors that have their own pressure, so that indirectly socio-economic factors can also influence the incidence of one's hypertension. Purpose: to analyze the relationship between socio-economic conditions and stress levels with the incidence of hypertension. Methods. This type of research is descriptive correlational with a cross sectional design that aims to examine the relationship between socio-economic conditions and stress levels with the incidence of hypertension. This study used a sample of 93 respondents with a simple random sampling technique. Result. The results of data analysis with the Spearman rank correlation test get a value $(\alpha: 0,000)$. Conclusion. There is a significant relationship which means there is a relationship between socio-economic and stress with the incidence of hypertension in the Sawan II Health Center Work Area.
\end{abstract}

Key words: Socio-economic, Stress and Hypertension

\section{Pendahuluan}

Hipertensi atau tekanan darah tinggi adalah peningkatan tekanan darah yang terjadi secara abnormal, secara umum dikatakan hipertensi jika tekanan darah di atas 140/90 mmHg (Herwati and Wiwi sartika, 2014). Hipertensi juga 
disebut the sillent killeratau pembunuh diam-diam, merupakan penyakit yang tidak menimbulkan gejala terlebih dahulu dan ditemukan secara kebetulan saat penderita datang kepelayanan kesehatan untuk memeriksa penyakit yang dideritanya (Sety, 2018). Apabila tidak terkendali, hipertensi dapat menimbulkan akibat yang lebih berat, amisalnya jantung koroner, ginjal, dan sakit paru-paru. Oleh sebab itu, penderita hipertensi sebaiknya mengontrol tekanan darah (Spruill, 2014).

Prevalensi hipertensi didunia menurut World Health Organization (WHO) yaitu penduduk umur $>18$ tahun mencapai 1 Milliar orang,jumlah penderita hipertensi diperkirakan akanterus meningkat seiring dengan jumlah penduduk yang bertambah pada 2025 mendatang, diperkirakan sekitar 29\% warga dunia terkena hipertensi.kawasan Afrika memegang posisi puncak penderita hipertensi, yaitu sebesar 40\%. Kawasan Amerika sebesar 35\% dan Asia Tenggara 36\%. Kawasan Asia penyakit ini telah membunuh 1,5 juta orang setiap tahunnya.Secara keseluruhan, negara-negara berpendapatan tinggi memiliki prevalensi lebih rendah yaitu 35\% dari kelompok berpenghasilan rendah dan menengah $40 \%$ yang mengalami hipertensi (Tarigan, Lubis and Syarifah, 2018).

Prevalensi hipertensi di Indonesia pada tahun 2013 menunjukkan bahwa secara nasional $25,8 \%$ penduduk Indonesia menderita penyakit hipertensi. Jika saat ini penduduk Indonesia sebesar 252.124.458 jiwa maka terdapat 65.048.110 jiwa yang menderita hipertensi (Kemnenkes RI, 2013). Provinsi Bali merupakan salah satu Provinsi di Indonesia dengan prevalensi penderita hipertensi dengan presentase $19,9 \%$ atau sekitar 840.851 jiwa dari keseluruhan jumlah penduduk provinsi bali sekitar 4.225.384 jiwa (Dinkes Provinsi Bali, 2017). Di Kabupaten Buleleng hipertensi menduduki peingkat kedua dalam 10 besar penyakit tidak menular yang terjadi di kabupaten buleleng dengan jumlah yaitu 17939 kasus (Dinas Kesehatan Kab. Buleleng, 2017).

Studi pendahuluan yang dilakukan di Puskesmas Sawan II Kecamatan Sawan Kabupaten Buleleng, yang dilakukan pada tanggal 28 Oktober 2018.Berdasarkan Informasi yang didapat dari salah satu petugas puskesmas yang berjaga, jumlah kasus hipertensi yang terjadi di Puskesmas Sawan II didapatkan data jumlah kunjungan pasien hipertensi pada 3 bulan terakhir sebanyak 120 
kasus. Dari jumlah tersebut studi pendahuluan dilakukan terhadap 8 orang pasien hipertensi mengatakan mengeluh sakit kepala,mudah tersinggung, sulit tidur dan mudah lelah yang disebabkan oleh tuntutan pekerjaan untuk kelangsungan ekonomi keluarga.

Faktor-faktor yang mempengaruhi kejadian hipertensi dibagi menjadi 2 faktor, meliputi faktor yang tidak dapat dikendalikan seperti jenis kelamin, umur, genetik dan ras, sedangkan faktor yang dapat dikendalikan seperti pola makan, kebiasaan olahraga, konsumsi garam yang tinggi, kopi, minuman alkohol dan stress (Artiyaningrum, 2016). Salah satu dari sekian faktor tersebut adalah faktor stres. Stres merupakan suatu kondisi atau keadaan tubuh yang terganggu karena tekanan psikologis dan biasanya stres dikaitkan dengan penyakit psikologis (Leka, Griffiths and Cox, 2015).

Stress merupakan suatu keadaan yang umum yang terjadi dalam kehidupan sehari-hari dan tidak dapat dihindari serta terjadi pada setiap orang(Windarsih, et al, 2017). Stres berkaitan dengan hipertensi. Fink (2016) mengungkapkan bahwa hubungan antara stres dengan kejadian hipertensi terjadi melalui aktivitas saraf simpatis. Peningkatan saraf dapat menaikkan tekanan darah secara intermiten (tidak menentu). Sehingga stres yang berkepanjangan dapat mengakibatkan tekanan darah cenderung tinggi. Stres akan meningkatkan resistensi pembuluh darah perifer dan curah jantung sehingga akan menstimulasi aktivitas saraf simpatis (Tim Bumi Medika, 2017).

Salah satu faktor penyebab terjadinya stres adalah terkait dengan masalah Status Sosial Ekonomi (SSE). Indonesia termasuk low middle income countries yang ditandai masih banyak masyarakat tinggal di daerah pedesaan dengan SSE rendah (Lio, 2014). Berdasarkan data statistika yang dilakukan pada bulan maret 2018 menunjukkan bahwa 25,95 juta orang atau 9,82\% penduduk Indonesia berada pada garis kemiskinan dengan pengeluaran perbulan dibawah Rp 374, 478. Dan untuk Provinsi Bali angka kemiskinan mencapai 171,76 ribu orang atau 4,72 \% (Badan Pusat Statistik, 2017). Status sosial ekonomi rendah dihubungkan dengan status kesehatan yang lebih buruk, hal tersebut terkait dengan tingkat pengetahuan, gaya hidup dan kualitas diet yang rendah atau kurang sehat (Windarsih, Suyamto and Devianto, 2017). 


\section{Metode Penelitian}

Penelitian ini menggunakan desain deskriptif korelasional dengan menggunakan rancangan penelitian cross sectional Populasi penelitian ini adalah penderita hipertensi di Wilayah Kerja puskesmas Sawan II sebanyak 120 orang.

Sampel dalam penelitian ini berjumlah 93 responden.Pengambilan sampel dalam penelitian ini denganNonprobability Sampling dengan teknik simple random sampling.Penelian ini dilaksanakan di wilayah kerja puskesmas sawan II dari tanggal 22 April - 11 Mei 2019.

Alat yang digunakan untuk mengumpulkan data pada penelitian ini adalah lembar angket penghasialan responden, kuesioner depression anxiety and stress scala 21 dan lembar observasi tekanan darah dengan alat bantu tensimeter.setelah data terkumpul selanjutnya akan dilakukan pengolahan data dengan uji spearmant rank menggunakan aplikasi spss16.0 for windows.

\section{Hasil}

\section{Analisis Univariat}

Tabel 1. Karakteristik Responden

\begin{tabular}{lcc}
\hline \multicolumn{1}{c}{ Karakteristik } & $\mathbf{n}=\mathbf{9 3}$ & $\mathbf{\%}$ \\
\hline Usia & 4 & \\
$31-40$ & 16 & 6,5 \\
$41-50$ & 31 & 18,8 \\
$51-60$ & 36 & 35,3 \\
$61-70$ & 6 & 40,1 \\
$71-80$ & & 8,4 \\
Jenis Kelamin & 50 & 43 \\
Laki-laki & 53 & 57 \\
Perempuan & & \\
Pendidikan & 17 & 18,3 \\
Tidak Sekolah & 32 & 34,4 \\
SD & 20 & 21,5 \\
SMP & 13 & 14,0 \\
SMA & 11 & 11,8 \\
Perguruan Tinggi & & \\
Pekerjaan & 29 & 31,2 \\
Petani & 29 & 31,2 \\
Buruh & 20 & 21,5 \\
Swasta & 15 & 16,1 \\
PNS & & \\
Sosial Ekonomi & 65 & 69,9 \\
Sosial Ekonomi Rendah & 28 & 30,1 \\
Sosial Ekonomi Tinggi & & 24,7 \\
Tingkat Stres & 23 & \\
Normal & &
\end{tabular}


Intan Husada : Jurnal Ilmiah Keperawatan, Vol. 7 No. 2, Juli 2019

\begin{tabular}{llc}
\hline \hline & & \\
\hline Stres Ringan & 35 & 37,6 \\
Stres Sedang & 25 & 26,9 \\
Stres Berat & 10 & 10,8 \\
Kejadian Hipertensi & & \\
Terjadi Hipertensi & 69 & 74,2 \\
$\quad$ Tidak Terjadi Hipertensi & 24 & 25,8 \\
\hline
\end{tabular}

\section{Analisis Bivariat}

Tabel 2. Hubungan Sosial Ekonomi dan Stres Dengan Kejadian Hipertensi

\begin{tabular}{lcccc}
\hline \multicolumn{1}{c}{ Variabel } & $\begin{array}{c}\text { Tidak Terjadi } \\
\text { Hipertensi }\end{array}$ & $\begin{array}{c}\text { Terjadi } \\
\text { Hipertensi }\end{array}$ & $\begin{array}{c}\text { Corelation } \\
\text { Coefficient }\end{array}$ & $\begin{array}{c}\text { P } \\
\text { Value }\end{array}$ \\
\hline Sosial Ekonomi & 12 & & & \\
$\quad$ Sosial Ekonomi Rendah & 16 & 53 & & \\
$\quad$ Sosial Ekonomi Tinggi & 16 & 12 & $-448^{* *}$ & 0,000 \\
Tingkat Stres & 14 & 9 & & \\
$\quad$ Normal & 8 & 27 & $0,352^{* *}$ & 0,001 \\
Stres Ringan & 4 & 21 & & \\
Stres Sedang & 1 & 9 & & \\
$\quad$ Stres Berat & & & & \\
\hline
\end{tabular}

\section{Pembahasan}

\section{Karakteristik Responden}

Dari hasil lembar observasi ditemukan bahwa didapatkan bahwa rata-rata umur responden yang mengalami hipertensi adalah 60 tahun. Hal ini menunjukkan bahwa hipertensi sebagian besar diderita oleh dewasa tua sampai lansia. Hal ini ditemukan juga dalam penelitian Atmojo et al (2019) rerata umur responden yang mengalami hipertensi di atas 60 tahun. Ditemukan kecenderungan peningkatan prevalensi hipertensi menurut peningkatan usia. Menurut Lu et al., (2015) hal ini disebabkan karena tekanan arterial semakin meningkat seiring bertambahnya usia, terjadinya regurgitasi aorta, serta adanya proses degenerative yang lebih sering terjadi pada usia tua.

Dilihat dari karakteristik responden berdasarkan jenis kelamin peneliti menemukan bahwa sebagian besar responden yang mengalami hipertensi sebagian besar berjenis kelamin perempuan. Menurut Donsu (2017), pada dasarnya prevalensi hipertensi primer antara laki-laki dan perempuan sama namun sebelum mengalami menopause, wanita terlindung dari penyakit kardiovaskular karena aktivitas hormone esterogen yang berperan dalam meningkatkan kadar HDL. Pada premenopause wanita kehilangan sedikit demi sedikit hormone esterogen yang selama ini melindungi pembuluh darah dari kerusakan. Proses ini terus berlanjut 
dimana hormone esterogen berubah kuantitasnya sesuai dengan umur wanita secara alami.

Peneliti menemukan bahwa dari tolal 93 responden yang diteliti sebagian besar responden memliliki latar belang pendidikan yang rendah yaitu hanya berpendidikan SD yaitu sebanyak 32 orang $(34,4 \%)$ dan banyak juga ditemukan responden yang sama sekali tidak pernah mengenyam pendikan atau tidak pernah sekolah yakni sebanyak 17 orang (18,3\%). Tingginya resiko terkena hipertensi pada golongan masyarakat dengan tigkat pendidikan rendah, kemungkinan disebabkan karena kurangnya pengetahuan seseorang yang berpendidikan rendah terhadap kesehatan sulit atau lambat dalam menerima informasi. Pendidikan merupakan indikator tingkat kemampuan manusia dalam memahami akses informasi yang diperoleh dari luar, dalam hal ini kaitnnya dengan informasi dari kesehatan berkaitan dengan kesadaran untuk mau memeriksakan diri serta mengetahui komplikasi-komplikasi lanjutan dari hipertensi ermasuk mengetahui gejala-gejala awal dari hipertensi (Nascimento-Ferreira et al., 2015).

Peneliti juga menemukan bahwa mayoritas responden dengan hipertensi berasal dari kalangan pekerjaan buruh dan petani. Mungkin hal ini dikarenakan faktor kurangnya biaya untukmemeriksakan diri secara teratur serta tekanan psikologis berkaitan dengan himpitan ekonomi. Faktor pendapatan sendiri juga berhubungan dengan kejadian hipertensi hal ini lebih dikarenakan karena kemampuan materi dan kemudahan akses dalam mendapatkan akses pelayanan kesehatan yang memadai dan akses informasi kesehatan yang mudah baik dari media cetak maupun elekttronik.

\section{Analisis hubungan sosial ekonomi dengan kejadian hipertensi di wilayah kerja Puskesmas Sawan II.}

Dari hasil penelitian tentang hubungan sosial ekonomi dengan kejadian hipertensi di wilayah kerja Puskesmas Sawan II didapatkan bahwa dari seluruh responden yang berjumlah 93. Responden dengan status sosial ekonomi tinggi dan tidak terjadi hipertensi sebanyak 18 responden atau $(64,2 \%)$ responden dengan status sosial ekonomi tinggi dan terjadi hipertensi sebanyak 10 responden $(35,8 \%)$. Sedangkan reponden dengan status sosial ekonomi rendah dan terjadi 
hipertensi sebanyak 54 responden $(83,1 \%)$ responden dengan status sosial ekonomi rendah dan tidak terjadi hipertensi sebanyak 11 responden $(16,9 \%)$. Sedangkan dari hasil uji analisis menggunakan uji spearmant rank didapatkan bahwa nilai sig $<\alpha(0,013<0,05)$ yang berarti dapat disimpulkan bahwa ada hubungan yang signifikan antara Sosial ekonomi dengan kejadian hipertensi di wilayah kerja Puskesmas Sawan II.

Pendapat yang sama juga diungkapkan Psaltopoulou et al., (2017) dengan hasil penelitiannya bahwa pada tingkat kelompok berpenghasilanrendah memilikipeningkatanrisiko hipertensi lebih tinggi dibandingkan dengan kelompok berpenghasilan tinggi. Studi metaanalisis yang dilakukan oleh Asfaw (2016) mengatakan bahwa negara dengan penghasilan rendah dan menengah menunjukkan hasil signifikan untuk terjadinya hipertensi. Menurut Kharisyanti \& Farapti (2017) status sosial ekonomi mempunyai makna suatu situasi yang mengarah pada kemampuan finansial keluarga dalam perlengkapan material yang dibutuhkan, dimana keadaan ini bertaraf baik, cukup, dan kurang. Ada lima faktor yang mempengaruhi sosial ekonomi, dua diantaranya dinilai memiliki pengaruh bagi kesehatan yaitu faktor pendidikaan dan pendapatan.

Orang dengan status sosial ekonomi tinggi cenderung memiliki tingkat pendidikan yang tinggi, hasil dari pendidikan terkait kesehatan adalah dalam bentuk kesadaran kesehatan. kesadaran kesehatan merupakan keadaan padaseseorang dimana di situ terdapat pemahaman mengenai kesehatan pada diri seseorang. kesadaran kesehatan menjadi titik yang menentukan sejauh mana seseorang mengerti dan memahami mengenai kesehatan. pemahaman itu bisa berbentuk tindakan, pengetahuan,maupun upaya pencegahan untuk tetap menjaga kesehatan pada dirinya agar tetap optimal (Nascimento-Ferreira et al., 2015).

Dalam penelitian dilapangan, peneliti menemukan mayoritas responden sosial ekonomi rendah dengan penghasilan yang rendah. Menurut Dubey et al., (2014) salah satu indikator yang paling penting dalam menentukan status sosial ekonpomi seseorang adalah dari faktor pendapatan, yang bersumber dari sektor formal, sektor informal dan sektor subsistem dalam waktu satu bulan yang diukur berdasarkan rupiah. Tingkat pendapatan dapat dikaitkan dengan daya beli seseorang.Pendapatan yang tinggi mampu memberikan daya beli yang memiliki 
kualitas yang terjamin pula khususnya dalam konsumsi sehari-hari.Sebaliknya terhadap pendapatan yang rendah, maka daya beli khususnya konsumsi keluarga seperti rendahnya konsumsi buah dan sayur juga kurang lengkap dan variatif.Sehingga hal ini dapat menjadi faktor tingginya prevalensi hipertensi. Data sistematik review di negara berkembang membuktikan pola konsumsi yang kurang sehat pada masyarakat SSE rendah dapat dijelaskan oleh lebih mahalnya harga "healthier diets".

Menurut peneliti hipertensi sebagian besar terjadi pada kalangan masyarakat dengan status sosial ekonomi rendah. Hal ini mungkin disebabkan karena kurangnya kemampuan ekonomi individu atau keluarga dalam memenuhi kebutuhan kesehatan termasuk didalamnya diet yang sehat untuk hipertensi, treatmen atau medikasi yang baik dan memadai. Kurangnya mendapat informasi kesehatan juga dapat menjadi faktor penyebab. Dilihat dari arah hubungannya negatif artinya semakin tinggi tingkat sosial ekonomi, maka semakin rendah kejadian hipertensi.Tingkat sosial ekonomi yang rendah dapat menjadi faktor risiko hipertensi.Kebanyakan dari mereka merupakan masyarakat dengan ekonomi menengah ke bawah, yang lebih banyak menggunakan penghasilannya untuk memenuhi kebutuhan pokok daripada memeriksakan kesehatan.Bahkan terkadang meskipun telah mengetahui bahwa dirinya menderita hipertensi, mereka mengabaikan nasihat dari petugas kesehatan tentang pengobatan hipertensi, karena kecenderungan orang-orang yang hidup sendiri dan daya ingatnya sudah mulai menurun.

\section{Analisis hubungan tingkat stres dengan kejadian hipertensi di wilayah kerja Puskesmas Sawan II.}

Dari hasil penelitian karakteristik responden berdasarkan tingkat stres di wilayah kerja puskesmas Sawan II dapat dilihat bahwa dari seluruh responden yang berjumlah 93. responden dengan tidak stres atau normal dan tidak terjadi hipertensi sebanyak 14 responden $(66,7 \%)$, responden dengan tidak stres dan mengalami hipertensi sebanyak 7 responden $(33,3 \%)$ hal ini dikarenakan selain tingkat stres juga ada banyak faktor yang mempengaruhi hipertensi seperti faktor konsumsi garam berlebih, obesitas, kurang berolahraga, faktor genetic, usia dan 
merokok. Sedangkan responden dengan stres dan tidak terjadi hipertensi sebanyak 10 responden $(13,9 \%)$, dan responden dengan stres dan mengalami hipertensi yaitu sebanyak 62 responden $(86,1 \%)$. Selanjutnya dilakukan uji analisi menggunakan uji spearmant rank dan didapatkan hasil bahwa nilai sig $<\alpha$ $(0,000<0,05)$ yang berarti ada hubungan yang signifikan antara tingkat stres dengan kejadian hipertensi di wilayah kerja Puskesmas Sawan II.

Menurut Jadhav et al., (2014) stres tidak menyebabkan hipertensi yang menetap, namun stres dapat mengakibatkan terjadi peningkatan tekanan darah yang tinggi untuk sementara waktu. Pernyataan ini didukung oleh teori dari Donsu (2017) menyatakan bahwa hubungan stres dengan hipertensi diduga melalui aktivasi saraf simpatis (saraf yang bekerja saat beraktivitas). Peningkatan aktivasi saraf simpattis dapat menyebabkan peningkatan tekanan darah secara intermitten (tidak menentu). Apabila stres berkepanjangan akan menyebabkan tekanan darah menjadi tetap tinggi.

Berdasarkan teori dari Leka, Griffiths and Cox (2015) stres dapat dijadikan stimulus untuk perubahan dan perkembangan, sehingga dalam hal ini dapat dianggap positif. Meskipun demikian stres yang terlalu berat dapat mengakibatkan sakit, penilaian yang buruk, dan ketidakmampuan untuk bertahan. Kondisi ini dapat menimbulkan berbagai perubahan atau gangguan baik fisik maupun psikologis dari pasien. Salah satu kategori penyebab stres yaitu stres fisiologis.

Stres fisiologis merupakan stres yang disebabkan ganggguan fungsi organ tubuh, antara lain gangguan struktur tubuh, fungsi jaringan dan organ. Stres fisiologis dapat membuat perubahan dalam metabolisme tubuh, dapat menyebabkan kerja jantung meningkat, dan terjadi peningkatan tekanan darah $(\mathrm{Hu}$ et al., 2015). Menurut Bhelkar, et al, (2018) Pada umumnya stres dapat mempengaruhi dari pada kondisi kesehatan seseorang termasuk mempengaruhi tekanan darah seseorang. Mekanisme bagaimana stres mempengaruhi tekanan darah dimulai ketika seseorang mengalami stres, Secara fisiologi, saat seseorang mengalami stres tubuh merespon dengan mengaktivasi hipotalamus, selanjutnya hipotalamus mengendalikan dua sistemneuroendokrin, yaitu sistem simpatis dan sistem korteks adrenal. Sistem saraf simpatik berespons terhadap impuls saraf dari hipotalamus yaitu dengan mengaktivasi berbagai organ dan otot polos yang 
berada di bawah pengendaliannya, yang menyebabkan meningkatnya kecepatan dan kekuatan denyut jantung. Sehingga tekanan darah meningkat.

Menurut peneliti pada umumnya stres dapat mempengaruhi dari pada kondisi kesehatan seseorang termasuk mempengaruhi tekanan darah seseorang. hal ini disebabkan karena terjadi peningkatan aktiviasi saraf simpatis (saraf yang bekerja saat kita berakivitas). Apabila stres berkepanjangan maka akan mengakibatkan tekanan darah akan menjadi tetap tinggi. Hipertensi sebenarnya merupakan penyakit yang dapat dicegah. Salah satu pencegahan yang dapat digunakan adalah dengan mengurangi faktor risiko penyebab hipertensi (Patil and Durairaj, 2015). Namun demikian banyak para ahli berpendapat stress hanya bersifat sementara. Artinya, jika keadaan jiwa tenang kembali, tekanan darah juga akan turun. Mengalami keadaan stress terus- menerus menyebabkan tubuh terkondisi dengan tekanan darah yang rata-rata tinggi (Tim Bumi Medika, 2017).

\section{Kesimpulan}

Status sosial ekonomi responden di wilayah kerja Puskesmas Sawan II pada tanggal 22 April - 11 Mei 2019 didapatkan hasil responden dengan status sosial ekonomi rendah yaitu sebanyak 58 responden $(69,9 \%)$ dan responden dengan status sosial ekonomi tinggi yaitu sebanyak 35 responden $(30,1 \%)$.Tingkat stres pada responden di wilayah kerja Puskesmas Sawan II pada tanggal 22 April - 11 Mei 2019 didapatkan hasil responden dengan stres sebanyak 70 responden (76,3\%) dan responden dengan tidak mengalami stres sebanyak 23responden $(24,7 \%) . K e j a d i a n$ hipertensi pada responden di wilayah kerja Puskesmas Sawan II pada tanggal 22 April - 11 Mei 2019 didapatkan hasil responden dengan terjadi hipertensi sebanyak 69 responden $(74,2 \%)$ dan responden yang tidak terjadi hipertensi yaitu sebanyak 24 responden atau (25,8 \%).Sehingga dapat disimpulkan bahwa ada hubungan yang signifikan anatara keadaan sosial ekonomi dan tingkat stres dengan kejadian hipertensi di wilayah kerja Puskesmas Sawan II.

\section{Daftar Pustaka}

Artiyaningrum, B. (2016) 'Faktor-Faktor Yang Berhubungan Dengan Kejadian Hipertensi Tidak Terkendali Pada Penderita Yang Melakukan Pemeriksaan Rutin di Puskesmas Kedungmundu Kota Semarang Tahun 2016', Public Health Perspective Journal, 1(1), pp. 12-20. 
Asfaw, S. (2012) 'Contribution of Risk Factors to Socioeconomic Variation in Blood Pressure: the Tromsø study’.

Atmojo, J. T. et al. (2019) 'EFEKTIFITAS TERAPI RELAKSASI BENSON TERHADAP TEKANAN DARAH PADA PENDERITA HIPERTENSI', Interest: Jurnal Ilmu Kesehatan, 8(1). Available at: https://jurnalinterest.com/index.php/int/article/view/117 (Accessed: 2 July 2019).

Badan Pusat Statistik (2017) 'laporan bulanan data sosial ekonomi’.

Bali, D. K. P. (2017) 'Profil kesehatan Provinsi Bali 2017'.

Bhelkar, S. et al. (2018) 'Association between Stress and Hypertension among Adults More Than 30 Years: A Case-Control Study', National Journal of Community Medicine, 9(6), pp. 430-433.

Dinas Kesehatan Kab. Buleleng (2016) Profil Kesehatan Kabupaten Buleleng Tahun 2016. doi: 10.1016/j.fitote.2010.04.009.

Dubey, R. K. et al. (2014) 'Effect of Contemporary Lifestyle and Socioeconomic Status on Hypertension in Eastern U.P., India', International Research Journal of Pharmacy, 4(12), pp. 50-52. doi: 10.7897/2230-8407.041211.

Fink, G. (2016) 'Stress: Definition and history', Encyclopedia of Neuroscience, (January 2016), pp. 549-555. doi: 10.1016/B978-008045046-9.00076-0.

Herwati and Wiwi sartika (2014) 'Terkontrolnyatekanan Darahpenderitahipertensi Berdasarkanpoladietdankebiasaanolahraga Dipadangtahun 2011', 8(1), pp. 814.

$\mathrm{Hu}$, B. et al. (2015) 'Effects of psychological stress on hypertension in middleaged Chinese: A cross-sectional study', PLoS ONE, 10(6), pp. 1-13. doi: 10.1371/journal.pone.0129163.

Jadhav, S. B. et al. (2014) "Stressing "mental stress" in hypertension: A rural background study', Journal of Clinical and Diagnostic Research, 8(6), pp. 710. doi: 10.7860/JCDR/2014/8209.4506.

Kemnenkes RI (2013) 'pusat data dan informasi kementrian kesehatan RI', pp. 147-160. doi: 10.1177/109019817400200403.

Kharisyanti, F. and Farapti, F. (2017) 'Status Sosial Ekonomi Dan Kejadian Hipertensi', Media Kesehatan Masyarakat Indonesia, 13(3), p. 200. doi: 10.30597/mkmi.v13i3.2643.

Leka, S., Griffiths, A. and Cox, T. (2015) 'Work organisation and stress: systematic problem approaches for employers, managers and trade union 
representatives', Protecting Workers' Health Series No. 3, (3), pp. 1-27. doi: 9241590475 1729-3499.

Lio, M. (2014) 'Hubungan antara status sosial ekonomi dengan anemia pada ibu hamil di desa sapa kecamatan tenga kabupaten minahasa selatan'.

Lu, Y. et al. (2015) 'Lifestyle and risk of hypertension: Follow-up of a young prehypertensive cohort', International Journal of Medical Sciences, 12(7), pp. 605-612. doi: 10.7150/ijms.12446.

Nascimento-Ferreira, M. V. et al. (2015) 'Prevalence of cardiovascular risk factors, the association with socioeconomic variables in adolescents from Low-Income region | Prevalencia de factores de riesgo cardiovascular, la asociación con las variables socioeconómicas en los adolescentes en región', Nutricion Hospitalaria, 31(1), pp. 217-224. doi: 10.3305/nh.2015.31.1.7511.

Patil, M. and Durairaj, M. (2015) 'Risk factors of hypertension among adult men: Evidence from a real world outcomes investigation in a Western Indian population', International Journal of Advanced Research Journalwww.journalijar.com INTERNATIONAL JOURNAL OF ADVANCED RESEARCH, 3(7), pp. 274-282.

Psaltopoulou, T. et al. (2017) 'Socioeconomic status and risk factors for cardiovascular disease: Impact of dietary mediators', Hellenic Journal of Cardiology. Elsevier Ltd, 58(1), pp. 32-42. doi: 10.1016/j.hjc.2017.01.022.

Sety, A. 2 S. Y. 3 L. O. M. (2018) 'Faktor Risiko Antara Aktivitas Fisik, Obesitas Dan Stres Dengan Kejadian Penyakit Hipertensi Pada Umur 45-55 Tahun Di Wilayah Kerja Puskesmas Soropia Kabupaten Konawe Tahun 2018', 3(2), pp. 1-10.

Spruill, T. (2014) 'Chronic Psychological Stress and Hypertension', Curr Hypertens Rep, 12(1), pp. 10-16. doi: 10.1007/s11906-009-0084-8.Chronic.

Tarigan, A. R., Lubis, Z. and Syarifah (2018) 'Pengaruh Pengetahuan, Sikap Dan Dukungan Keluarga Terhadap Diet Hipertensi Di Desa Hulu Kecamatan Pancur Batu Tahun 2016', 11(1), pp. 8-16. doi: 10.24252/kesehatan.v11i1.5107.

tim Bumi Medika (2017) Berdamai dengan Hipertensi. Edited by I. Sari. jakarta: Bumi Medika.

Tim Bumi Medika (2017) Berdamai dengan Hipertensi. Edited by yanita nur. jakarta: Bumi Medika.

Tine donsu, jenita doli (2017) Psikologi keperawatan, Aspek - Aspek Psikologi, Konsep Dasar Psikologi dan Teori Perilaku Manusia. Edited by Elisa. Yogyakarta: PUSTAKA BARU PRESS. 
Windarsih, A. D., Suyamto, S. and Devianto, A. (2017) 'Hubungan antara stres dan tingkat sosial ekonomi terhadap hipertensi pada lansia', Jurnal Keperawatan Notokusumo, 5(1), pp. 62-71. 